\title{
THE INDETERMINATE FORM OF HUMAN CHRONIC CHAGAS' DISEASE A CLINICAL EPIDEMOLOGICAL REVIEW
}

\author{
João Carlos Pinto Dias
}

\begin{abstract}
Data on the epidemiology and the natural history of the indeterminate form of human chronic Chagas' disease (IFCCD) are discussed, revealing its great importance in endemic areas of Brazil. The work shows that IFCCD presents a gradual and very slow course, causing a benign picture in the studied patients. Evolution patterns, prognostic and anatomo-pathological features are also discussed.

For practical purposes, the classical concept of IFCCD proved to be simple, operational and consistent, It is defined by the absence of symptoms and clinical findings in chronic infected patients with positive serology and/or parasitological examinations for Trypanosoma cruzi coupled with normal electrocardiographic and radiological exams (heart, oesophagus and colon $X$-Rays). If a patient is submitted to more rigorous and sophisticated tests, these can reveal some alterations, generally small ones and unable to interfere with the prognosis of the infection.

It is suggested that research lines specially related to the evolution ary factors and immunological involvement during this phase be adopted.
\end{abstract}

Key-words: Chagas' disease. Indeterminante form. Prognosis. Evolution factors.

The indeterminate form of human chronic Chagas' disease (IFCCD) has had very great epidemiological importance in endemic areas. In 1916, Carlos Chagas 11 introduced the term "indeterminante", to indicate "the absence of predominant clinical syndromes" while, in 1923 , E. Villela 50 wrote that "the indeterminate form has no single description; it is recognized only as a temporary stage of the provisional classification of the cases that will be developing toward one of the clinical forms, or as a latent phase in which the lack of clinical signs will give the appearance of perfect health". Also called "laboratorial form" or "latent phase", or even "sub-clinical" form, IFCCD generally comprises more than half of the infected population in Brazilian endemic areas 18293238 .

The general concept of IFCCD has an "operational" nature, as pointed out by the Laranja's et al. classic paper of 195629 . "The asymptomatic period, described as the chronic indeterminate form of the disease, comprises a long period, usually from 10 to 20 years, between the end of the acute stage and the establishment of the late heart disease of chronic

Federal University of Minas Gerais and Ministry of Health, Brazil. Work in part sponsored by TDR (UNDP/WB/WHO) and CNPq, Brazil.

Address: Centro de Pesquisas René Rachou CP 1743, 30000, Belo Horizonte, MG, Brazil.

Recebido para publicação em 19/11/88. infection. During the asymptomatic period individuals may be considered as belonging to the category of potential cardiac patients. In the endemic areas this group of asymptomatic chronic infection is the largest of the three groups of patients with $T$. cruz $i$ infection. Although these patients are apparently healthy and asymptomatic, they most important from the epidemiological standpoint". With the more recent descriptions of the chronic digestive forms of the disease $^{2242}$ this concept must incorporate the absence of the symptoms and signs of the major digestive "pathies", the oesophageal and colonic chagasic dysperistalsis 63544 .

The present concept earned general acceptance with the beginning of the longitudinal studies of Chagas'disease in endemic and non-endemic Brazilian areas in the sixties 132131 and was formally discussed in official documents in $1971^{35}$ and 197421. In November 1984, a very distinguished group of Brazilian experts was brought together by the Conselho Nacional de Desenvolvimento Científico e Tecnológico to discuss IFCCD, and expressed the classical concept in the following terms 41 : "Considering the existing controversies on the validity of the concept of the so-called indeterminate forms of Chagas'disease, and also unfavourable repercussion for the patient from the medical, social and laboural points of view, the participants of the First Meeting of Applied Research on Chagas'Disease, taking place in Araxá (MG, Brazil), from December 13th to 15th 1984, 
Dias JCP. The indeterminate form of human chronic Chagas' disease. A clinical epidemiological review. Revista da Sociedade Brasileira de Medicina Tropical 22: 147-156, Jul-Set, 1989

decided to establish the following as criteria for its characterisation:

1. Serological and/or parasitological positivity;

2. Absence of symptoms and/or signs of the disease;

3. Normal conventional electrocardiogram; images.

4. Normal heart, oesophagus and colon X-ray

The Group considered it convenient to maintain this concept of the indeterminate form in clinical evaluation and epidemiological studies, taking into account the good prognosis for the cases.

Finally, the Group emphasised that, when submitted to more sensitive examination methods, chagasic patients included in the criteria above can show some changes, but this fact does not invalidate the concept here expressed".

IFCCD normally shows its highest incidence in the first 10 or 15 years of the infection, immediately after the acute phase; this includes the younger group of patients in endemic areas 1832 . It must be emphasised that the acute period of the disease passes unnoticed, with few or no symptom, in the great majority of the cases 182029 . This "inapparent" form of acute Chagas' disease was described by G. Teixeira 48 in 1977 , having A. Teixeira ${ }^{47}$ detected immunosuppresive phenomena in these patients.

Nevertheless, this inapparent acute Chagas' disease must not be confused with IFCCD, since the patients present at least some fever and positive fresh blood examinations. As described by Laranja et al ${ }^{29}$, the simplest criteria to distinguish the end of acute phase are the subsidence of the acute clinical manifestations and the reduction of the number of trypanosomes in the blood to such levels that can no longer be detected on fresh examination. One very important consideration about this transitional period between the end of the acute and the beginning of the chronic phase is the possibility of a parasitological cure for many patients, since adequate specific treatment may be performed at this time ${ }^{9} 17$.

Generally, the IFCCD begins a few weeks or months after the acute phase, as shown by longitudinal studies. Among 317 symptomatic acute patients followed in Bambui (MG, Brazil) the great majority of the cases passed to the chronic "latent" period in the first six months after the beginning of the infection; the fever and clinical picture disappeared first and the normalisation of ECG and cardiac X-rays were observed later. Nevertheless, in a few natients a persistent cardiac involvement could be observed after the acute episode, with ECG disturbances (PR enlargement or $T$ wave disturbances) and/or persistent cardiac enlargement for several years, even in the absence of fever, cardiac failure of other important symptoms. In a few other cases it was noted that IFCCD had a very short duration (one or two years) after the acute phase, since heart of oesophagic chronic involvement were soon detected ${ }^{18}$. Finally, in another small group of patients, there was a variable period of between two and five years during which transient episodes of an acute heart involvement (chiefly electrocardiographic disturbances) alternated with typical IFCCD, until the establishment of persistent IFCCD or definite chronic form.

The general picture of the possible courses for human Chagas'disease can be summarised in Figure 112. This shows both Chagas' and Villela's concept of IFCCD as a transitionary form of the disease, as well as the more recent view that some cases can remain permanently in this condition 519293238 .

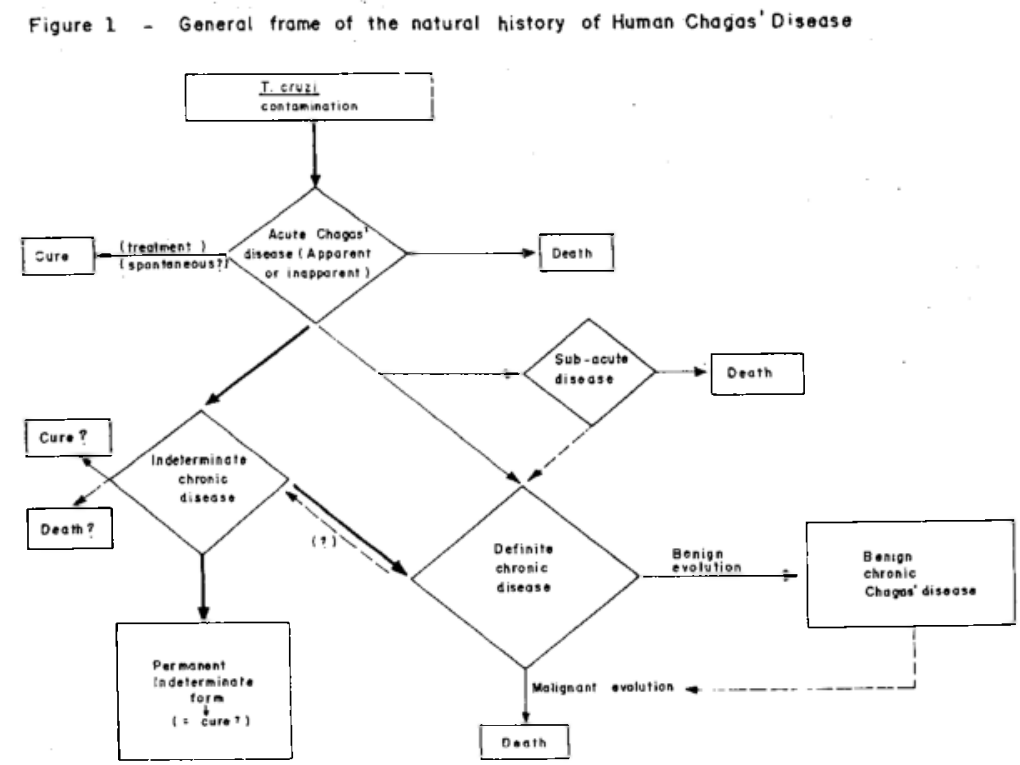


in Table 3. This study was performed in an endemic area of Bahia State, Brazil, with a non-selected general population. The IFCCD group represented $50 \%$ of the chagasic patients of the area and was made up of individuals of both sexes, mostly young people ( $50 \%$ under 20 years of age).

Table 3 - Clinical forms to which 400 individuals with the indeterminate chronic form of Chagas' disease in Bahia, Brazil evolved in 10 years of follow-up ${ }^{32}$.

\begin{tabular}{lrr}
\hline Clinical Forms* & n. & $\%$ \\
\hline Cardiac I & 62 & 16 \\
Cardiac II & 22 & 6 \\
Cardiac III & 6 & 2 \\
Cardiac IV & 1 & 0 \\
Oesophagic involvement & 5 & 1 \\
Without evolution & 304 & 76
\end{tabular}

* Chronic cardiopathy classified according to the severity of cardiac disease; $I$ is the initial and less severe degree 631 .

Data are also very similar in other endemic Brazilian areas 1418 and even in a longitudinal study performed in Buenos Aires 33 .

In Minas Gerais State, Coura and Pereira 14 have determined the evolution of 76 cases followed for 6 years in the Northeast and 57 cases followed for 10 years in the West of the State (Table 4).

Table 4 - Evolution of indeterminate form of Chagas' disease in two endemic areas in Minas Gerais, Brazil ${ }^{14}$.

\begin{tabular}{lrr}
\hline \multirow{2}{*}{ Evolution } & \multicolumn{2}{c}{ Percent evolution } \\
& Northeast & West \\
\hline Initial heart disease & 33 & 35 \\
Severe cardiac involvement & 3 & 5 \\
Oesophagal dysperistalsis & 6 & 5 \\
Unaltered & 58 & 54 \\
& & \\
\end{tabular}

The potential of IFCCD for determining the evolution into the symptomatic form seems to be higher among young male than among females patients up to 40 years 91825 . According to Macedo, $50 \%$ of the indeterminate patients who evolved into the symptomatic form were in the age group between 10 and 20 years; $40 \%$ between 21 and 49 and only $10 \%$ were under 50 years old ${ }^{32}$.

The long term evolution of patients with IFCCD is generally very favourable, and they usually die of causes other than Chagas' disease. Mortality data on these patients are available in some longitudinal studies such as those of Macêdo ${ }^{32}$, Dias ${ }^{18}$, Dias and Kloetze $\mathrm{l}^{23}$ and Forichon ${ }^{25}$ showing a very good quod vitam prognosis for the patient between five and ten years after the diagnosis, in any age group. For instance, in the São Felipe study only eight patients died amongst 400 individuals presenting the indeterminate form, seven of them due to non-chagasic causes and one because of acute chagasic myocarditis due to reinfection ${ }^{32}$. In the Bambui study, none of the 37 patients followed up since the acute onset who died in the chronic phase was in the indeterminate form ${ }^{18}$. Forichon 25 , still in Bambui, verified that not more than $3 \%$ amongst 885 adult chagasic patients without cardiac involvement died during the following 10 years, whilst the general mortality reached $30 \%$ for female and $45 \%$ for male patients with chagasic chronic cardiopathy.

Similar data were obtained by Coura and Perei$\mathrm{ra}^{14}$ who followed 116 indeterminate patients for six years and 130 for ten years, with no deaths, in an endemic area of Minas Gerais. These data suggest once more, as did very early Carlos Chagas' and Laranja et al that the main cause of death from Chagas' disease is still the severe heart involvement. Therefore, since the most common evolution pattern of IFCCD is to initial benign cardiopathy (Table 3 ), it is easy to understand why the immediate and medium-term prognoses of patients are so good.

The general prevalence of IFCCD is about $50 \%$ among all chagasic people in endemic areas ${ }^{14} 38$. Longitudinal and cross sectional specific studies must take into account the age groups of the population, since the major evolution potential belongs to the younger groups and also because it is sometimes very difficult to reach conclusions about Chagas' disease in older ages 18 33. In other words, because of the evolutive potential of some patients, those in IFCCD must be closely observed by the primary health services. Early detection of heart involvement makes the clinical management of chronic chagasic cardiopathy much easy 1726 . Unfortunately, it seems that specific treatment of patients in the indeterminate form results neither in cure (except for some young patients) 240 nor in the interruption of the evolution course ${ }^{8}$. Manzullo and Darraidou ${ }^{33}$ observed 185 chronic patients during eight years or more, part of them treated with Nifurtimox and the other part untreated. Both these groups had normal ECG's and X-rays at the beginning of the study, and electrocardiographic disturbances emerged at an annual rate of $6.6 \%$ and $6.7 \%$ respectively.

Race, sex, concomitant or intercurrent diseases, nutritional status and alcoholism are some general factors that must affect the natural history of the disease 236131819202538 . Work is a very important factor that was recently discussed by Faria et al 24 
Dias JCP. The indeterminate form of human chronic Chagas' disease. A clinical epidemiological review. Revista da Sociedade Brasileira de Medicina Tropical 22: 147-156, Jul-Set, 1989

who showed the very high exercise performance of adult rural workers with IFCCD (group I) in comparison with normal individuals and chagasic patients with complete right bundle branch block (groups II and III). Table 5 summarises these results.

The good work performance of individuals with IFCCD is generally accepted. The interference of work with the clinical course of this form is still not completely clear. It seems that some individuals can remain asymptomatic all their lives in endemic areas, in spite of very hard physical work ${ }^{18} 32$. But it is also true that high physical effort can interfere in cardiac equilibrium producing pathophysiologic changes in the myocardial units that, in chagasic hearts, could induce progressive degrees of cardiac failure 418192628

The evolution towards the "clinical" forms is directly related to the duration of the disease. As Prata and Macedo ${ }^{38}$ have observed "the longer this time the more chance there is of cardiopathy appearing".

Parasitemia per se does not appear to modify the course of chronic Chagas' disease, according to Castro ${ }^{10}$ and Dias ${ }^{18}$. Nevertheless Pifano ${ }^{37}$ states that cardiac involvement is more likely to appear in individuals with a high parasitemia, measured by xenodiagnosis.

Dias $^{16}$ and Macêdo $^{31}$ suggest that the clinical evolution may also be influenced by reinfections, but

Table 5 - Chagas' disease and work. Exercise parameters for chagasic rural workers with the indeterminate form (Group I), and those with complete right bundle block (Group III) compared with non-chagasic (Group II) rural workers 19 .

\begin{tabular}{|c|c|c|c|c|}
\hline \multirow{2}{*}{\multicolumn{2}{|c|}{ Number of individuals }} & \multirow{2}{*}{$\begin{array}{l}\text { Group I } \\
28\end{array}$} & \multirow{2}{*}{ Group II } & \multirow{2}{*}{$\begin{array}{l}\text { Group III } \\
9\end{array}$} \\
\hline & & & & \\
\hline \multicolumn{2}{|c|}{ Caucasoid/negroid } & $22 / 6$ & $26 / 2$ & $7 / 2$ \\
\hline \multicolumn{2}{|c|}{ Smokers/non-smokers } & $15 / 13$ & $13 / 15$ & $4 / 5$ \\
\hline \multicolumn{5}{|c|}{ Physical activity } \\
\hline \multicolumn{2}{|c|}{$\mathrm{High} / \mathrm{medium} / \mathrm{low}$} & $22 / 5 / 1$ & 23/4/1 & $6 / 1 / 2$ \\
\hline Can ride a bic & & 25 & 25 & 8 \\
\hline \multicolumn{5}{|c|}{ Blood pressure, lung and } \\
\hline \multicolumn{2}{|c|}{$\begin{array}{l}\text { Hematocrit } \\
\text { Other diseases }\end{array}$} & Normal & Normal & Normal \\
\hline \multirow{2}{*}{\multicolumn{2}{|c|}{$\begin{array}{l}\text { Other diseases } \\
\text { Cardiac area }\end{array}$}} & Absent & Absent & Absent \\
\hline & & Normal & Normal & Normal \\
\hline \multicolumn{2}{|l|}{ EKG } & Normal & Normal & RBBB \\
\hline \multicolumn{2}{|c|}{ Serology to Chagas' disease } & Positive & Negative & Positive \\
\hline Age (years) & & $30.6 \pm 6.8$ & $30.1 \pm 6.8$ & $34.2 \pm 4.1$ \\
\hline Height $(\mathrm{cm})$ & & $166.2 \pm 4.9$ & $168.1 \pm 6.1$ & $168.8 \pm 8.5$ \\
\hline Weight (kg) & & $58.5 \pm 7.5$ & $56.8 \pm 8.8$ & $57.0 \pm 7.7$ \\
\hline Fat $\%$ & & $11.5 \pm 2.8$ & $11.3 \pm 2.2$ & $10.9 \pm 2.6$ \\
\hline Lean body ma & s (kg) & $51.6 \pm 5.6$ & $51.3 \pm 5.3$ & $50.7 \pm 6.1$ \\
\hline Health-Carter' & somatotype & $2.6-4.9-2.9$ & $2.4-4.4-3.3$ & $2.3-4.4-3.6$ \\
\hline Maximal load & attained (w) & $204 \pm 31$ & $206 \pm 49$ & $189 \pm 33^{*}$ \\
\hline Pulse (bpm) & At rest & \pm 10 & \pm 8 & $67 \pm 13$ \\
\hline & Maximum & $187 \pm 12$ & 188 & $165 \pm 18^{*}$ \\
\hline Systolic blood & pressure $(\mathrm{mmF}$ & & & \\
\hline & At rest & $119 \pm 13$ & $188 \pm 10$ & \pm 12 \\
\hline & Maximum & $182 \pm 12$ & $181 \pm 16$ & $185 \pm 35$ \\
\hline & At rest & 5 & 3 & $6 * * * *$ \\
\hline Exercise & & 8 & 9 & $7 * *$ \\
\hline (No of cases) & Recovery & 5 & 8 & $7 * *$ \\
\hline Test & Maximal & $24^{*}$ & 28 & $7 *$ \\
\hline & Sub-maximal & $4 *$ & 0 & $2 *$ \\
\hline Less than sub- & naximal & 0 & 0 & 0 \\
\hline Symptoms & Exercise & 1 & 0 & 0 \\
\hline & Recovery & 0 & 0 & 0 \\
\hline
\end{tabular}


this factor did not appear to be important in the longitudinal study in Bambui ${ }^{18}$.

As remarked above, the acute episode influences the clinical course of the chronic phase 3182239 . Andrade $^{2}$ stresses that IFCCD generally means a general picture of inactive scarce inflammatory foci remaining from the acute phase, with few possibilities of evolution. As suggested by Koberle 28 the autonomous denervation, chiefly occurring in the acute phase, can result in clinical chronic signs, which depend on the physiological balance between the involved functions and the number of neurons destroyed. In the chronic phase, the acute denervations is slowly increased by a slight chronic denervation and also by age-dependent physiological denervation 3842 . The anatomical substrate of IFCCD was studied chiefly by Chapadeiro ${ }^{12}$, Andrade ${ }^{2}$ and Lopes et a ${ }^{30}$. Generally the digestive tract of the patients with this form presents some degree of intramural autonomous denervation, with or without scarce detectable chronic inflammatory foci 32844 . General para-sympathetic denervation is nearly always present in Brazilian patients with IFCCD, but this condition is not frequently detectable in some other endemic countries such as Venezuela and Central America 1844 . On the other hand, as stressed by Rezende ${ }^{44}$, "the greatest variation in the level of denervation seen among infected individuals belonging to the same community or the same family, points to the existence of important immunological factors linked to the host".

In the heart, the systematic studies performed in asymptomatic individuals who have died in accidents can be summarised as follows 1230 :

a) The volume and the weight of these hearts are within normal limits.

b) Macroscopically, about $90 \%$ of the hearts present thick white pericardic formations sometimes presented as little plaques, or as tendinous spots, or even as rosary-form nodes; microscopically these formations represent an active chronic pericarditis that can reach some autonomic nervous intracardiac ganglia or threads;

c) The myocardium generally presents a macroscopically normal aspect, but sometimes can become thin $(10 \%)$ and, more rearely, shows wall aneurysms. The myocardial features in IFCCD commonly consist of lympho-plasmocytic infiltrations that are small and scarce, but sometimes can constitute larger foci with associated myocytolysis. There are frequent tiny fibrotic scars in some parts of the myocardium. In dogs that survived acute disease, Andrade ${ }^{1}$ verified several degrees of cicatricial lesions in the myocardium, in the conducting tissue of the heart and in intra-cardiac vagal neurons. He concluded that "it was apparent that the destructive changes occurring during acute infection and involving struc- tures that cannot regenerate will leave cicatricial areas in the heart and, presumably, elsewhere. Will such cicatricial lesions in the conducting tissue and autonomic nervous system be responsible for the positivity of the refined tests when cardiac function is explored in asymptomatic Chagas' patients?"

d) The inflammatory process is more evident in the region of the vertex;

e) The endocardium is generally normal, but in a few cases may be thickened because of fibroblastic proliferation;

f) The finding of amastigote forms of the parasite is exceptional.

As a more general conclusion, Lopes et al ${ }^{30}$. have stated that inflammatory lesions are always observed in all chagasic patients and that different levels of involvement in the heart of patients with IFCCD may explain at least in part, the clinical differences amongst the cases. These authors also stated that it is very difficult to establish the evolutive potential of the focal lesions observed in patients with IFCCD.

The long silent period between the acute infection and the late cardiac manifestations of chronic Chagas' disease still remains without an adequate explanation. When chronic myocarditis starts, it apparently assumes a self-perpetuating mechanism and progresses until the death of the host. Although it is not known the nature of the antigens ${ }^{9}$ responsible for the main lesions, there is a general assumption that they result from mechanisms of hypersensitivity ${ }^{1}$. Andrade ${ }^{1}$ thinks that all the markers of hypersensitivity are found in hosts that present either IFCCD or in chronic chagasic heart disease. "One is therefore tempted to suggest that diferences in the two conditions may lie in the state of immunological suppressive factors which, while they seem to be successful during the indeterminate stage, appear to have been overcome to allow for the development of chronic progressive myocarditis ${ }^{1}$. On the same subject, Ribeiro-dos-Santos and Rossi 45 stated that it was possible to detect in patients with IFCCD a M-immunoglobulin able to block the hypersensitivity reactions of homologous cells. These results "suggest that, in the chronic phase of Chagas' desease, hypersensitivity mechanisms (or even cellular auto-immune responses against myocardial factors) are started which, in normal conditions and immunological balance, would be blocked and unable to produce histological lesions". In other words, the organism in normal conditions would be able to modulate the auto-immune response while it is producing an anti-auto-immune reaction ${ }^{17}$. Some experimental studies with cyclophosphamide in dogs with IFCCD ${ }^{1}$ show that the immunodepressive effect of the drug was able to induce some minor electrocardiographic disturbances, especially after Ajmaline administration, stressing the idea that such a pathogenetic 
Dias JCP. The indeterminate form of human chronic Chagas' disease. A clinical epidemiological review. Revista da Sociedade Brasileira de Medicina Tropical 22: 147-156, Jul-Set, 1989

pathway depends on a delayed-type hypersensitive mechanism ${ }^{12}$.

In spite of the several evolutive possibilities of IFCCD ${ }^{15} 19$, or even the accumulated data about histological, haemodynamic and pharmacological disturbances that can be detected in some of these cases 1518 it must be stressed that classical definition of IFCCD is above all, a practical and operational concept based on two main considerations:

a) This concept is sufficiently simple to be useful in any kind of area or medical service. Besides serological diagnosis, it demands no more than a good clinical examination, a conventional ECG and simple $\mathrm{x}$-ray apparatus able to perform chest examinations, oesophagic barium meal transit studies and simple contrast examinations of the colon 6313544 .

b) The concept itself is very consistent, since the patients labelled as "indeterminate" really present very good work performance and an immediately favourable clinical evolution in most of the reported cases 13141824323338 .

Nevertheless, using "secondary" more sophisticated methods, cardiac and oesophagic abnormalities may appear in "indeterminated" patients 153841 . Therefore, within the classical concept of IFCCD, two main groups of patients can be distinguished: those individuals whose results remain normal and those who show some alterations with "secondary" examinations. As stressed by Prata and Macêdo 38, it is difficult to determine whether these two groups have a different prognosis. Histopathological changes verified in cardiac biopsies ${ }^{15}$, small and transient atrioventricular conduction abnormalities after vagolytic drug administration ${ }^{38}$, echocardiographic ${ }^{36}$, vectocardiographic ${ }^{15}$, haemodynamic ${ }^{15}$ and cardiac autonomic disturbances 27 are some alterations that can be detected in patients with IFCCD. Also incipient neuro-motor incordination may emerge in manometric oesophagic studies ${ }^{43}$. Psychological disturbances can also be detected in the "asymptomatic" patients, as pointed out by Vieira ${ }^{49}$, since autonomic denervation occurs in the acute phase and the day life tensions can induce them to be hyperreactive (stressed) to the different environmental stimuli.

These considerations do not invalidate the classical concept of IFCCD, as mentioned in the Araxá document ${ }^{41}$. The really pertinent problems on the correct definition of the indeterminate form concern chiefly the operational aspects of the basic diagnosis, namely:

a) A consistent serologic diagnosis, involving, at least, two concordant serological tests;

b) A correct and detailed clinical examination, taking into account the basic aspects of the disease. Official guidelines for this examination have been published by WHO and $\mathrm{CNPq}^{6} 35$ and must be used both in individual and population studies;

c) The precise and homogeneous interpretation of the ECG, in order to eliminate the concessions in interpretation pointed by Decourt et al ${ }^{15}$. (The same considerations can be applied to the radiological examination, concerning both interpretation and technical aspects). TDR and other institutions are trying to standardise specific criteria and guidelines to make these examinations comparable in every area;

d) The consistent differential diagnosis with other prevalent diseases. For this it is very important to establish the real "chagasic component" of heart or digestive problems in individuals. For instance, young patients with IFCCD can be affected by idiopathic myocardiophaties, whilst old chagasic patients may present presbioesophagus, hypertensive or myocardic sclerotic lesions without any participation of Chagas' disease in such disturbances 1729 . In most epidemiologic and comparative studies the patients with other heart and/or digestive problems must be removed even it they are in IFCCD.

For practical purposes, the basic clinical examination of patients in IFCCD can be improved with minimal resources, even in field work. The various workshops of the TDR and the National Scientific Councils 635 , and the accummulated experience of the Brazilian longitudinal and crossectional studies suggest the following simple procedures for patient analysis:

Clinical Examination: Anamnesis must be reliable. Heart and digestive symptoms are often underrated by the patients and must be correctly explored. It is also important to distinguish when hypocondriac patients (or people that are hoping for social security benefits) are stressing some general and/or vague symptoms. Clinical signs of the main chronic syndromes must be looked for in detail, chiefly the initial heart failure and cardiac arrythmias, Apart from a long and detailed cardiac auscultation, observation of the pulse for one minute or more is useful in detecting incipient ectopic beats ${ }^{17} 35$. Some ambulatorial non-invasive procedures such as the Valsalva and hyperventilation manoeuvers are also very useful in detecting cardiac arrythmias in apparently heathy individuals 1724 .

Basal ECG: This is the most important auxiliary method in the study of human chronic Chagas' disease 52935 . It is necessary to establish electrocardiographic normality, as well as to record a sufficient number of cardiac complexes to detect easily ectopic heart beats ${ }^{33}$. ECG may be accompanied either by Valsalva or hyperventilation manoeuvres or by simple pharmacological tests 38 .

Effort tests: They probably constitute the best non-invasive procedure to explore heart function in 
Dias JCP. The indeterminate form of human chronic Chagas' disease. A clinical epidemiological review. Revista da Sociedade Brasileira de Medicina Tropical 22: 147-156, Jul-Set, 1989

IFCCD. As verified by Faria et $a^{24}$, ergometric tests can detect heart function degeneration earlier than resting ECG, $\mathrm{X}$-ray studies and clinical examinations. Several years of using the cycloergometric test has proved its safety, but it must be emphasised that risks do exist and the procedure must be performed carefully and by trained personnel ${ }^{24}$.

Certainly the asymptomatic chagasic patients with a "negative" effort test will have much better prognosis quod vitam than those with increased readings. The value of ergometry is unquestionable in Chagas' disease. The use of this procedure must be stimulated both in research and clinical care services, in endemic countries.

The digestive forms of chronic Chagas' disease are usually detected by anamnesis plus contrasted Xray examinations 173544 . Nevertheless some problems can be present for IFCCD characterisation, since border-line oesophagic or colonic dysperistalsis can occur ${ }^{18} 43$. Incipient colopathy without "mega" seems to be very frequent in some endemic areas, with a progressive and very slow evolution, presenting transitory periods of constipation and with a radiological picture showing only some degree of sygmoid elongation ${ }^{18}$. Should these individuals be considered to be in the indeterminate form?

Autonomic denervation seems to appear in different degrees, in chagasic patients of different endemic areas 3272844 . Many patients with IFCCD may show signs of denervation when submitted to simple neurological tests 2728 . Such neurological aspects might receive more attention and general research, but probably a low or moderate level of denervation will not interfere with the classical concept of IFCCD. As a matter of fact, denervation phenomena in chronic Chagas' infection generally progress very slowly or even remain stable, frequently being tolerated by the individual, with no clinical manifestations 1828 . In terms of peripheral and central nervous systems, the usual neurological examinations are generally completely negative 17 .

\section{Final Remarks}

The epidemiological importance of IFCCD and the related laboral and medical aspects constitute a reason to vigorously strengthen the research on this form of American Trypanosomiasis.

The multicentric investigation must be obviously standardised looking for epidemiological, operational, clinical, anatomical, therapeutical and immunological aspects.

The evolutionary aspects of the IFCCD must be investigated more completely including work on laboratory models, in order to clarify the risk factors, and the possible therapeutic avenues.

The clinical management of these patients shoud be more completely detailed, giving special attention to diagnostic aspects and operational procedures to be transferred to the primary health care system.

Laboral aspects of IFCCD also need more research, chiefly in order to determine up to what limit physical effort influences the natural history of the group.

Immunological and immunochemical studies must be stimulated along two main lines:

a) Attempts to discover a marker in the host able to indicate whether the disease is in evolution or not.

b) Attempts to clarify the mechanism and elements of the disease evolution, in order to establish the basis for the prevention of this evolution

\section{RESUMO}

Analisam-se epidemiologia e a história natural da forma indeterminada da doença de Chagas (FCI), confirmando-se sua grande importância epidemiológica em áreas endêmicas da tripanosomose, no Brasil. Os dados mostram que a evolução da FCI é geralmente lenta, com bom prognóstico, discutindo-se alguns fatores evolutivos, o prognóstico e o substrato anatomopatológico desta entidade.

Sob o prisma prático, verifica-se que o conceito clássico da FCI se mostra simples, consistente $e$ operacional: define-se no paciente crônico e assintomático, portador de provas sorológicas elou parasitológicas positivas para $\mathrm{T}$. cruzi, com exames clínico, eletrocardiográfico e radiológico (área cardíaca, esófago e cólon) normais. Exames outros mais rigorosos e sofisticados podem demonstrar algumas alteraçōes e anormalidades nestes pacientes, geralmente discretas e pouco interferentes no prognóstico.

Fazem-se algumas sugestões de pesquisa sobre a FCI, principalmente com relação ao envolvimento imunológico e a fatores de evolução.

Palavras-chaves: Doença de Chagas. Forma indeterminada. Prognóstico. Fatores de evoluçāo.

\section{ACKNOWLEDGEMENT}

The author gratefully acknowledges Drs. Humberto Guerra, Garret Capel-Williams and Stephen J. Hampson for their precious help in the final revision of this manuscript.

\section{REFERENCES}

1. Andrade ZA. The canine model of Chagas' disease. Memórias do Instituto Oswaldo Cruz 79 (supl.): 77-83, 1984.

2. Andrade ZA. A patologia da doença de Chagas no homem. Annales de la Societe Belge de Medecine Tropicale 65 (Suppl.): 15-30, 1985. 
Dias JCP. The indeterminate form of human chronic Chagas' disease. A clinical epidemiological review. Revista da Sociedade Brasileira de Medicina Tropical 22: 147-156, Jul-Set, 1989

3. Andrade ZA, Andrade SG. Patologia. In: Brener Z, Andrade ZA. Trypanosoma cruzi e Doença de Chagas. Guanabara Koogan Ed., Rio de Janeiro p. 199-248, 1979.

4. Bogliolo L. As causas anatômicas da insuficiência cardiaca na cardiopatia (miocardite) chagásica crônica In: Décourt LV, Campos OM (coord.). Modernos Conhecimentos sobre Doença de Chagas. Universidade $\mathrm{Fe}$ deral de Minas Gerais, Academia Mineira de Medicina. Belo Horizonte p. 283-302, 1981.

5. Brasil A. Evolução e prognóstico da doença de Chagas. Arquivos Brasikeiros de Cardiologia 18: 365-380, 1965.

6. Brasil/Conselho Nacional de Pesquisa. Epidemiologia da doença de Chagas. Objetivos e metodologia dos estudos longitudinais. Relatório Técnico no 1, 46 p., 1974.

7. Brener Z. O parasito: relações hospedeiro-parasito. In: Brener Z, Andrade ZA. Trypanosoma cruzi e Doença de Chagas. Guanabara Koogan Ed. Rio de Janeiro p. 1-41, 1979.

8. Brener Z. Recent advances in the chemotherapy of Chagas' disease. Memórias do Instituto Oswaldo Cruz, 79(supl.): 149-155, 1984.

9. Cançado JR: Tratamento especifico. In: Cançado JR, Chuster M. Cardiopatia Chagásica. Fundação Carlos Chagas, Belo Horizonte p. 327-355, 1985.

10. Castro $\mathrm{CN}$. Influência da parasitemia no quadro clínico da doença de Chagas. Revista de Patologia Tropical 9: 73-136, 1980.

11. Chagas C. Pathogenic processes of American Trypanosomiasis. Memórias do Instituto Oswaldo Cruz 8: 3-38, 1916.

12. Chapadeiro E. Histopatologia cardíaca na forma indeterminada da Doença de Chagas. In: Anais do Congresso Internacional sobre Doença de Chagas, Rio de Janeiro, p.0-9 - 0-11, 1979.

13. Coura JR Evolutive pattern in Chagas'disease and the life span of Trypanosoma cruzi in human infection. American Trypanosomiasis Research. Proceedings of an International Symposium PAHO/WHO Science Public 318 (Washington, USA) p. 378-383, 1976.

14. Coura JR, Pereira JB. A follow-up evaluation of Chagas' disease in two endemic areas in Brazil. Memórias do Instituto Oswaldo Cruz 79(Supl.): 107-112, 1984.

15. Decourt LV. Sosa EA, Mady C. Forma indeterminada: conceito e aspectos fisiopatológicos. In: Cançado JR, Chuster M. Cardiopatia Chagásica. Fundação Carlos Chagas, Belo Horizonte p. 121-127, 1985.

16. Dias E. Efeitos da superinfecçāo sobre a evolução da cardiopatia crônica chagásica. Revista Goiana de Medicina 9(Supl.): 223-229, 1962.

17. Dias JCP. Clínica e terapêutica da doença de Chagas. Secretaria de Estado da Saúde, Belo Horizonte 74. p. 1981.

18. Dias JCP. Doença de Chagas em Bambui, Minas Gerais, Brasil. Estudo clínico-epidemiológico a partir da fase aguda, entre 1940 e 1982. Tese. Faculdade de Medicina, UFMG, Belo Horizonte, 1982.

19. Dias JCP. Etiopatogenia e história natural da doença de Chagas humana. Boletim Informativo Cenetrop 9: 28-35, 1983.
20. Dias JCP. Acute Chagas' disease. Memórias do Instituto Oswaldo Cruz 79 (Supl.): 85-92, 1984.

21. Dias JCP. História natural da cardiopatia chagásica. In: Cançado JR, Chuster M. (organ.) Cardiopadia Chagásica. Fundação Carlos Chagas, Belo Horizonte 99-113, 1984.

22. Dias JCP. Epidemiology of Chagas' disease in Brazil. In: Brenner RR, Stoka A (coord.). Chagas' Disease Vectors. CRS Press. Ed. Boca Raton, FI. USA, 1987.

23. Dias JCP. Kloetzel K. The prognostic value of the electrocardiographic features of chronic Chagas' disease. Revista Instituto Medicina Tropical São Paulo 10: 158-162, 1968.

24. Faria CAF, Dias JCP, Cintra ML, Rodrigues LO. Chagas'disease and work. In: Anais do Congresso Internacional sobre Doença de Chagas, Rio de Janeiro p. J-2 - J-7, 1979

25. Forichon $\mathrm{E}$. Contribuition aux estimations de morbidité et de mortalité dans la maladie de Chagas. Tese. Universidade Paul Sabatier, Toulouse, França, 47 p. 1974.

26. Guimarães AC. $O$ tratamento da insuficiência cardíaca no chagásico. In: Anais do Congresso Internacional sobre Doença Chagas. Rio de Janeiro p. 5-8 - 5-13, 1979.

27. Junqueira JRL, Veiga JPR. Avaliação ambulatorial da função autonômica cardíaca nas diversas formas clínicas da moléstia de Chagas. Revista da Sociedade Brasileira de Medicina Tropical 17 (Supl.): 19, 1984.

28. Koberle F. Chagas' disease and Chagas' syndromes: the pathology of American Trypanosomiasis. Advances in Parasitology 6: 63-116, 1968.

29. Laranja FS. Dias E, Nóbrega G, Miranda A. Chagas' disease: a clinical, epidemiologic and pathologic study. Circulation 14: 1035-1060, 1956.

30. Lopes ER, Chapadeiro E, Rocha A. Anatomia patológica do coração na forma indeterminada. In: Cançado JR, Chuster M. Cardiopatia Chagásica. Fundação Carlos Chagas, Belo Horizonte p. 33-40, 1985.

31. Macedo VO. Influência da exposição à reinfecção na evolução da doença de Chagas. (Estudo longitudinal de cinco anos). Revista Patologia Tropical 5: 33-116, 1976.

32. Macedo VO. Forma indeterminada da doença de Chagas. Jornal Brasileiro de Medicina 38: 34-40, 1980.

33. Manzullo H, Darraidou AC. 1 . Estudio longitudinal de la cardiopatia chagásica crônica. Faculdade de Ciências Médicas, Buenos Aires (mimeogr.), 141 p. 1982.

34. Melo RC. Distribuição de parasitas intracelulares em animais inoculados com diferentes cepas de Trypanosoma cruzi. Tese. Departamento de Parasitologia, ICB, Universidade Federal de Minas Gerais, Belo Horizonte, 52 p., 1977.

35. OMS/OPS. Aspectos clínicos de la enfermedad de Chagas. Informe de una reunión conjunta OMS/OPS de investigadores. Boletín de la Oficina Sanitaria Panamericana 76: 141-158, 1974.

36. Ortiz J. Aspectos ecocardiográficos. In: Cançado JR Chuster M. Cardiopatia Chagásica. Fundação Carlos Chagas, Belo Horizonte p. 165-168, 1984.

37. Pifano F. La miocardiopatia chagásica crônica en el medio rural venezolano. Gaceta Médica de Caracas 85 : 17-30, 1977. 
Dias JCP. The indeterminate form of human chronic Chagas' disease. A clinical epidemiological review. Revista da Sociedade Brasileira de Medicina Tropical 22: 147-156, Jul-Set, 1989

38. Prata A, Macedo V. Morbidity of Chagas' heart disease. Memórias do Instituto Oswaldo Cruz 79 (Supl.): 93-96, 1984.

39. Ramirez Giraldo LE. O coelho como modelo experimental no estudo da doença de Chagas crônica. Tese. Universidade Federal de Minas Gerais, Belo Horizonte, 1984.

40. Rassi A. Tratamento etiológico da doença de Chagas. In: Resumos do $X V I I$ Congresso da Sociedade Brasileira de Medicina Tropical, Caldas Novas, p. 180-200, 1981.

41. I Reunião Anual de Pesquisa Aplicada em Doença Chagas. Validade do conceito de forma indeterminada de doença de Chagas. Revista da Sociedade Brasileira de Medicina Tropical 18: 46, 1985.

42. Rezende JM. Manifestações digestivas da moléstia de Chagas. In: Cançado JR. Doença de Chagas. Imprensa Oficial, Belo Horizonte p. 442-480, 1968.

43. Rezende JM. Exploração da motilidade do esôfago e do intestino grosso na forma indeterminada da doença de Chagas. In: Anais do Congresso Internacional sobre Doença Chagas, Rio de Janeiro p. 0-1 - 0-4, 1979.

44. Rezende JM. The digestive tract in Chagas' disease.
Memórias do Instituto Oswaldo Cruz 79 (Supl.): $97-$ 106, 1984.

45. Ribeiro dos Santos R, Rossi MA. Imunopatologia. In Cançado JR, Chuster M. Cardiopatia Chagásica. Fundação Carlos Chagas, Belo Horizonte p. 10-22, 1985.

46. Schlemper Jr BR. Caracterização de cepas de Trypanosoma cruzi isoladas de pacientes com diferentes formas clínicas da doença de Chagas. Tese, Universidade $\mathrm{Fe}$ deral Rio de Janeiro, Rio de Janeiro, 1982.

47. Teixeira ARL. Competencia imunológica do paciente chagásico. Imunodepressão na forma aguda inaparente. Auto-imunidade no hospedeiro imunizado. Tese de Doutorado. Universidade Federal de Minas Gerais, Belo Horizonte, 1981.

48. Teixeira MGLC. Doença de Chagas. Estudo da forma aguda inaparente. Tese de Mestrado, Universidade Federal do Rio de Janeiro, Rio de Janeiro, 1977.

49. Vieira CB. Manifestaçōes psíquicas na forma crônica da moléstia de Chagas. Exemplo de hiperreatividade orgânica. Revista Goiana de Medicina 10: 127-134, 1964.

50. Villela E. Moléstia de Chagas. Descrição clínica, 5: parte. Folha Médica, 4: 65-66, 1923.

This work is dedicated to the memory of Dr. Francisco da Silva Laranja Fo, who died recently. This simple homage remembersca great human figure and the fantastic scientific work of this Brazilian researcher who, with his colleagues Emmanuel Dias and Genard Nóbrega, really started a new era in the studies and knowledge of human Chagas' disease. 